\title{
Occurrence, distribution and virulence factors of clinically important Acinetobacter species recovered from selected freshwater resources in the Eastern Cape Province, South Africa
}

Mary Ayobami Adewoyin ( $\sim$ marymartin055@gmail.com )

University of Fort Hare https://orcid.org/0000-0001-7489-7402

Anthony Ifeanyi Okoh

University of Fort Hare

Research article

Keywords: Freshwater resources, Molecular characterisation, Acinetobacter species, virulence genes

Posted Date: January 27th, 2020

DOI: https://doi.org/10.21203/rs.2.14951/v2

License: (a) (i) This work is licensed under a Creative Commons Attribution 4.0 International License. Read Full License 


\section{Abstract}

Background : Several Acinetobacter species live in different ecosystems such as soil, freshwater, wastewater, and solid wastes. In this study, we assessed the occurrence of A. baumannii and A. nosocomialis, which are the major two clinically important species of the genus Acinetobacter, in three freshwater resources (Great Fish, Keiskemma, and Tyhume rivers) in the Eastern Cape Province, South Africa over a one year sampling regime (April 2017 - March 2018). Presumptive Acinetobacter species were subjected to molecular identification by using Acinetobacter genus-specific primers targeting the recA gene. The confirmed Acinetobacter species were further delineated into A. baumannii and A. nosocomialis using species-specific primer sets. Similarly, virulence genes, namely; afa/draBC, epsA, fimH, OmpA, PAl, $\mathrm{sfa} / \mathrm{focDE}$, and traT in the two Acinetobacter species were also determined using molecular techniques.

Result : A total of 1107 presumptive Acinetobacter isolates were recovered from the freshwater resources of which 844 was confirmed positive for the Acinetobacter genus. Of the 844 Acinetobacter isolates, 285 (77\%), 219 (70.9\%) and 340 (79\%) were recovered from Great Fish, Keiskemma and Tyhume rivers respectively. Our finding revealed that $410(48.58 \%)$ and $23(2.7 \%)$ of the isolates were confirmed to be $A$. baumannii and A. nosocomalis, respectively. The presence of these clinically-important Acinetobacter species in the freshwater studied suggests possible contamination of the selected rivers and also that $A$. baumannii and A. nosocomialis can thrive in aquatic environments. Besides, 308 (75.12\%) A. baumannii and $3(13.04 \%)$ A. nosocomialis isolates exhibited one or more virulence genes out of the seven tested, whereas $102(24.88 \%)$ and $20(86.95 \%)$ of the A. baumannii and A. nosocomialis isolates did not harbour any virulence gene. Additionally, OmpA was the most prevalent $(\mathrm{p}<0.05)$ virulence gene in A. baumannii with 69 (45.10\%), 52 (50.98\%) and 77 (49.68\%) isolates in Great Fish, Keiskamma and Tyhume rivers respectively.

Conclusion : The occurrence of these pathogens in rivers which are consumed by humans and livestock, as well as being used for irrigation system constitutes a risk to public health. Keywords: Freshwater resources, Molecular characterisation, Acinetobacter species, virulence gene $\mathrm{s}$.

\section{Background}

The majorities of Acinetobacter species are free-living and are ubiquitous in nature, but the clinicallyimportant species, most especially the Acinetobacter calcoaceticus- baumannii (ACB) complex, are frequently isolated from the hospital environs. Among members of this complex, A. baumannii, $A$. nosocomialis, and $A$. pittii are well-reported causative agents of Acinetobacter-related infections in hospitals around the globe [1, 2]. The most virulent Acinetobacter species, $A$. baumannii, is known to cause disease outbreaks in intensive care units (ICUs). Owing to the importance of this disease-causing species in the clinical settings, some scientists have reported that it is a nosocomial pathogen and its occurrence in other environments is likely not possible [2]. However, in recent discoveries, $A$. baumannii has been reported to thrive in freshwater, soil, healthy human skin just like other non-pathogenic species in the Genus $[3,4]$. The occurrence of $A$. baumannii and other pathogenic species of the genus Acinetobacter in other 
environment apart from the hospital could be associated with the indiscriminate disposal of wastewater and materials from the hospital into the environment [5].

The isolation of $A$. baumannii from hospitalized patients is often associated with serious ailment, with corresponding mortality rate of approximately $30 \%[6,7]$. Additionally, A. baumannii has been implicated in a range of diseases which includes; Acinetobacter pneumonia-bronchiolitis and tracheobronchitis $[8,9]$, bloodstream infection [2, 10], wound infection [11], urinary tract infection $[2,11]$ and meningitis $[8,12]$. Similarly, A. nosocomialis was responsible for bacteremia [13, 14], pneumonia [15], and induction of epithelial cell death and host inflammatory responses [16].

The pathogenicity of Acinetobacter species like other microorganisms is strongly associated with the virulence factors they harbour. These factors include porins (OmpA), capsular polysaccharides, lipopolysaccharides (LPS), phospholipase, outer membrane vesicles (OMVs), protein secretion systems, metal acquisition system etc. $[8,17,18,19]$. The $O m p A$ is a protein located on the outer cell membrane of the bacteria, which is responsible for the selective permeation of materials in and out of the cell. The OmpA also binds to the host epithelial cells in order to gain entry into the cell cytoplasmic environment. As such, it causes cell death (apoptosis) by releasing the cytochrome c. OmpA was also noted as one of the factors with which A. nosocomialis initiates its pathogenesis [20]. Pathogenic Gram-negative bacteria are known to secret outer membrane vesicles (OMVs) [17, 21, 22], for interaction between the bacterial pathogens and the host cells [23]. Kim and others [20] showed that $A$. nosocomialis uses its outer membrane vesicles (OMVs) for secretion of cytotoxic factors with which it elicits an immune response from host epithelial cell.

Phospholipase, like other factors, also contributes to the virulence of the pathogenic Acinetobacter species, by hydrolysing phospholipid bilayer of the host cell membrane in order to destabilize the entire cell $[17,24]$.

As a result, an investigation of the occurrence and distribution of these clinically-important Acinetobacter species in other environments, other than hospital, is very necessary for the understanding of what nature and diversity truly represent $[25,26]$. As such, the time has come to redefine the environmental coverage by these organisms, beyond a clinical setting. Therefore, the focus of this study was to assess the occurrence, distribution and the virulence factors of clinically-important Acinetobacter species such as A. baumannii and $A$. nosocomialis in the selected freshwater resources in the Eastern Cape, South Africa.

\section{Results}

\section{Isolation and distribution of presumptive Acinetobacter species}

A total of 1107 presumptive Acinetobacter species was recovered from the three rivers studied, of which 370,309 and 428 presumptive isolates belonged to Great Fish, Keiskemma and Tyhume rivers respectively as summarized in Table 1.

\section{PCR amplification of the recA gene}

To further validate the occurrence and distribution of the bacteria in the genus Acinetobacter in this study, the identification was achieved by using the PCR-based assay to detect internal recA genes that are specific 
to all Acinetobacter species. Figure S1 presents the PCR product of the gel electrophoresis and staining for the amplification of the $425 \mathrm{bp}$ fragment, which correlates to recA gene. Out of the 1107 presumptive isolates, 844 were confirmed to belong to the genus Acinetobacter of which $285(77 \%), 219(70.9 \%)$ and $340(79 \%)$ were recovered from Great fish, Keiskemma and Tyhume rivers respectively. The confirmed isolates belonging to the genus Acinetobacter is summarized and presented in Table 1.

\section{Delineation of Genus Acinetobacter into species}

Figures S2A and S2B shows the PCR products of the gel electrophoresis and staining for the delineation of the genus Acinetobacter into A. baumannii and A. nosocomailis accordingly, while $A$. pittii was not detected.

The occurrence of $A$. baumannii was 153 (53.68\%) in Great Fish river, 102 (46.58\%) in Keiskamma river, and 155 (45.59\%) in Tyhume river, while 16 (5.61\%), 3 (1.37\%) and 4 (1.18\%) represent $A$. nosocomialis from the respective rivers. The presence of $A$. baumannii in the three rivers studied was significantly higher $(p<0.05)$ than the $A$. nosocomialis isolates. The delineation into $A$. baumannii and $A$. nosocomailis are summarized and presented in Table 1.

\section{Detection of Virulence Genes}

The gel electrophoresis of the virulence genes; afa/draBC, epsA, fimH, OmpA, PAl, sfa/focDE, and traT, are presented in Figure S3. The virulence genes haboured by A. baumannii and A. nosocomialis in this study is presented in Figure 2 and summarized in Table 2. Additionally, the virulence gene(s) associated with each of the Acinetobacter species as well as the river source from which they were isolated is described. The statistical significance of the prevalence virulence genes with respect to rivers was also emphasized.

Three hundred and eight (75\%) of the 410 A. baumannii and $3(13 \%)$ of the 23 A. nosocomialis isolated from the rivers were observed to exhibit one or more virulence genes, out of the seven tested. Respectively, $102(24.88 \%)$ and $20(86.95 \%)$ of the A. baumannii and A. nosocomialis isolates from the three rivers did not harbour any of the virulence genes tested in this study. However, there was a significant difference $(p<0.05)$ in the prevalence of virulence genes harboured by A. baumannii compared to A. nosocomialis, though the population of the former was significantly higher than the latter in all cases.

The prevalence of virulence gene $a f a / d r a B C$ was significantly higher $(p<0.05)$ in the isolates from Great Fish river in comparison to Keiskamma and Tyhume rivers. However, there was a significant difference $(p<0.05)$ in prevalence between the $a f a / d r a B C$ genes haboured by the bacteria recovered from the Tyhume river when compared to those from Keiskamma river. Besides, the prevalence of traT gene in Acinetobacter species from Great Fish and Tyhume rivers showed no statistical difference $(\mathrm{p}<0.05)$, but both were significantly higher $(p<0.05)$ than those detected in isolates from Keiskamma river. Similarly, the prevalence of fimH gene detected in isolates recovered from Great Fish river was significantly higher $(p<0.05)$ than those detected in isolates from both Keiskamma and Tyhune river. Nonetheless, the proportion of isolates harbouring the gene in Keiskamma was significantly $(p<0.05)$ lower than those from Tyhume river. The prevalence of the PAI virulence gene was not significantly $(p<0.05)$ different in all the rivers studied. In Great 
Fish and Keiskamma rivers, there was no significant difference $(\mathrm{p}<0.05)$ in the prevalence of $s f a / f o c D E$ in isolates recovered from the rivers, but the proportion of Acinetobacter species in Tyhume harbouring the gene was significantly higher $(\mathrm{p}<0.05)$ than in those from both Great Fish and Keiskamma rivers. The number of Acinetobacter species harbouring epsA virulence gene in the Great Fish river was significantly higher $(p<0.05)$ than those recovered from Keiskamma river, but significantly lower $(p<0.05)$ than in Acinetobacter species recovered from Tyhume river. The prevalence of the $O m p A$ virulence gene was significantly higher $(\mathrm{p}<0.05)$ in $A$. baumannii isolates than all other virulence genes in this study. Besides, OmpA was the most prevalent virulence gene in the rivers, which represented 69 (45.10\%), 52 (50.98\%) and 77 (49.68\%) A. baumannii isolates in Great Fish, Keiskamma and Tyhume rivers respectively. The number of Acienotobacter species harbouring $O m p A$ gene in Great fish river were significantly higher $(p<0.05)$ than isolates from Keiskamma river, whereas Tyhume river maintained the highest level of statistical significance $(p<0.05)$ of the total Acinetobacter species exhibiting the virulence gene.

Summarily, OmpA was the most prevalent virulence gene detected in Acinetobacter species in all the three rivers studied followed by fimH and epsA genes, whereas PAl and Sfa/focDE genes were the least exhibited respectively. Furthermore, the number of Acinetobacter species habouring the highest percentage of virulence genes was isolated from the Tyhume River followed by the Great Fish River, while Kieskamma River was the least.

\section{Discussion}

Bacteria in the genus Acinetobacter have been known to colonize a wide array of ecological systems of which water, soil, sludge, wastewater, plants' root, and animals have been prominent. In this study, water samples were collected at five different sites from three selected rivers in the Eastern Cape Province, South Africa for the assessment of the oof Acinetobacter species. Several presumptive species belonging to the genus Acinetobacter were recovered from the water samples. Similar study was carried out by [27] on the microbial community in the urban riverine environment in Croatia, where 57 of the isolates belong to the genus Acinetobacter. Likewise, Krizova et al. [28], noted a widespread of $A$. bohemicus in the water environment in the Czech Republic. A. baumannii was characterized from a surface water resources in South Nation River (SNR) drainage basin in Eastern Ontario, Canada, in 2013 [26]. Besides, the composition of the bacterial community in a freshwater aquaculture environment was investigated in China by [29]. The study reported that the relative abundance of Acinetobacter species was $0.5 \%$ of the total bacterial community.

All isolates that were positive for the recA (425 bp) (Figure S1) were taken as belonging to the Acinetobacter genus, according to [30]. A PCR amplification assay based on recA gene-specific primer, identified 844 Acinetobacter species of the 1107 presumptive isolates, while $g y r B$ gene species-specific primers further delineated them into species namely, A. baumannii (410) and A. nosocomialis (23). According to [30], the method used in this study was $98.2 \%$ specific and $92.4 \%$ sensitive for Comparably, [31] demonstrated a PCR assay targeting recA gene A. baumannii, A. nosocomialis, and $A$. pittii are known nosocomial pathogens, which could cause multiple antibiotic resistant infections $[2,30,32]$ in immune-compromised patients [2]. Park and others [33] investigated the presence of Acinetobacter species in the bloodstream of 
patients with blood infection in a tertiary-care hospital in Korea between August 2003 and February 2010. Their findings showed that $A$. baumannii and $A$. nosocomialis were prevalent in the samples collected. Similarly, [34], recovered 160 A. baumannii isolates from sputum, blood, pus and fluid aspirates of patients in three Hospitals in Vietnam within a period of two years (between 2012 and 2014). These findings showed that the nosocomial pathogens could colonize any part of the human body to cause infections.

However, occurrence of $A$. baumannii and $A$. nosocomialis in an aquatic environment, is uncommon in the past few years. Nonetheless, in recent times, these nosocomial pathogens are isolated from other ecosystems $[3,4,35]$. The isolation of the pathogen from water sources might be due to contamination coming from hospital wastewater and materials.

The virulence traits of $A$. baumannii and $A$. nosocomialis have been a major research focus in recent times $[17,36]$. This is due to the nature of $A$. baumannii infections as well as the role virulence genes play in the pathogenicity of the emerging waterborne pathogen. Virulence genes are the mechanisms through which $A$. baumannii initiates pathogenesis [36, 37], most especially in the clinical settings.

In this study, molecular assay for the detection of virulence factors in both pathogens was performed. Figure $\mathrm{S} 2$ shows the electrophoretic images of the seven virulence factors evaluated. Although, $A$. baumannii had been confirmed to harbour several virulence factors (genes), seven of these genes ( $a f a / d r a B C, e p s A, f i m H, O m p A, \mathrm{PAl}, s f a / f o c D E$, and traT) are reported in this study. Reports on the virulence genes in $A$. baumannii are usually associated with isolates from clinical environment, whereas such reports are rare on $A$. baumannii from freshwater resources

Thus, this study showed that $O m p A$ gene was predominantly exhibited by the $A$. baumannii in all the rivers sampled, likewise fimH and epsA genes were also detected in many of the isolates, whereas afa/draBC, PAl, $S f a / f o c D E$, and traT genes were detected in a few Acinetobacter isolates. As such, the exhibition of virulence genes varies from one isolate to the other, which was also reported among clinical isolates known for nosocomial infections [38]. The OmpA gene is the main outer membrane protein (OMP) located on the A. baumannii membrane [39, 40], which [36]. These observations corroborate the findings of this current study which reports that the virulence profiles of an individual isolate varied greatly and OmpA gene was mostly detected [36].

Generally, the outer membranes of Gram-negative bacteria are made up of the OMPs, lipopolysaccharides and phospholipids layer [37]. The presence of outer membrane protein A gene (OmpA) in the A. baumanni isolated from the freshwater source is of a major concern based on its role in pathogenesis [36]. Besides, studies have shown that $A$. baumannii uses OmpA for adhesion to the lung epithelial cell by interacting with a cell cytoskeleton such as fibronectin on the cell surface and thereby inducing pneumonia [41, 42]. It also causes cell death through caspase-3 activation $[43,44]$. Similarly, A. baumannii could be responsible for apoptosis through the translocation of its OmpA into the mitochondria and the nucleus of host cells [45, 46]. The combination of the roles played by $O m p A$ makes it an important virulence factor in the pathogenesis of $A$. baumannii infection. Moreover, antibiotic resistance in $A$. baumannii is also associated with $O m p A[47,48]$. It was suggested that $O m p A$ was involved in the removal of antibiotics from the 
periplasmic space membrane efflux systems [48]. The survival and persistence of $A$. baumannii in the cell are enhanced by $O m p A$ due to the formation of biofilms and surface motility.

\section{Conclusions}

In this study, three selected freshwater resources in the Eastern Cape Province, South Africa were evaluated for the occurrence, distribution and virulence genes fingerprints of clinically-relevant Acinetobacter species namely; A. baumannii and $A$. nosocomialis. This study suggests that these pathogenic Acinetobacter species could also inhabit aquatic environment. As a result, aquatic environment is an important reservoir for pathogenic Acinetobacter species as detected in this study. Besides, the OmpA is a major virulence factor associated with $A$. baumannii and A. nosocomialis in this study. As such, identification of these opportunistic and virulent waterborne pathogens in the freshwater resources requires public awareness and recognition as important to public health risks.

\section{Methods}

\section{Description of study areas}

Collection of water samples was carried out from three rivers namely; Great Fish, Keiskamma and Tyhume, in the Eastern Cape Province, South Africa between April 2017 and March 2018. The Great Fish River is located in Chris Hani District Municipality in the Eastern Cape Province and it is one of the major rivers used for irrigation and livestock farming in the area. This river is prone to agricultural and municipal runoffs and also serves as the receiving stream of effluents from many wastewater treatment plants (WWTPs), especially those situated in urban communities such as Craddock. Keiskamma and Tyhume rivers are located in the Amathole District Municipality in the Eastern Cape Province and are exposed to different anthropogenic activities from the rural and urban communities along the river courses, such as livestock drinking and irrigation farming. In addition, these rivers receive effluents from wastewater treatment plants (WWTPs) situated close to their banks. Different sampling points on these rivers were selected based on where humans and animals come into direct contact with them, for example, points where they are used for fishing, drinking and swimming purposes, downstream of the WWTPs, points where irrigation water is released to the water bodies and proximity to hospital facilities.

\section{Sampling}

Water samples were collected at five different sites (S1, S2, S3, S4, and S5) from Great Fish, Keiskamma and Tyhume rivers respectively, for a period of one year, which covers the four seasonal patterns in South Africa (autumn, winter, spring, and summer). Water samples were collected aseptically in sterile $1 \mathrm{~L}$ glass bottles from different sampling points by midstream-dipping of sample bottles at 25-30 cm down the water column, with the mouth tilting against the flow of the river. All water samples were labelled properly and safely taken to the laboratory (in an ice chest) where they were processed within $6 \mathrm{~h}$ of collection [27]. Aliquots of water samples were used for isolation of Acinetobacter species based on standard microbiological procedures [49] 


\section{Isolation and purification of presumptive Acinetobacterspecies}

The isolation of the presumptive density of Acinetobacter species in the water samples was determined by membrane filtration technique [50]. Cellulose membrane of pore size $0.45 \mu \mathrm{m}$ was used to filter three volumes of $100 \mathrm{~mL}$ of the water samples under vacuum [50]. These membranes were aseptically placed on plates with Acinetobacter species selective medium-CHROMagar Acinetobacter base plus selective supplement (CHROMagar, Paris, France) which was prepared according to the manufacturer' instruction. Each sample plate was subjected to incubation at $37^{\circ} \mathrm{C}$ for $24 \mathrm{~h}$ after inoculation. Each sample was analysed in triplicate. All bacterial colonies with red colouration on the CHROMagar plates were counted as presumptive Acinetobacter species and were expressed as CFU/100ml. All isolates were sub-cultured on nutrient agar using a streak plate method (Oxoid, UK) and purified for further species identification. Fifty percent $(50 \%)$ glycerol stocks of the pure culture was prepared and stored at $-80{ }^{\circ} \mathrm{C}$.

\section{Molecular identification of Acinetobacterspecies by PCR assays}

Extraction of genomic DNA: Presumptive Acinetobacter spp. in glycerol stocks was first being resuscitated on tryptic soy broth and incubated for 18 to $24 \mathrm{~h}$ at $37^{\circ} \mathrm{C}$. DNA extraction from the bacterial isolates was carried out using the direct boiling method according to [51]. The broth culture was centrifuged at 15000 $r p m$ for 5 min using a Mini Spin Microcentrifuge (Lasec, RSA), then the supernatant was dispensed out and the pellet rinsed with sterile normal saline. The pellet was re-suspended in sterile distilled water and boiled in a heating block for 10 minutes using an AccuBlock (Digital dry bath, Labnet).

\section{Amplification of unique Acinetobacterspecies DNA}

Polymerase chain reaction (PCR) assay was used for the amplification of the Acinetobacter species recA gene as previously described [30]. The forward and reverse primers used were P-rA1 (5'CCTGAATCTTCTGGTAAAAC-3') and P-rA2 (5'-GTTTCTGGGCTGCCAAACATTAC-3') respectively. Briefly, an aliquot of $25 \mu$ containing Taq PCR (12.5 $\mu$ l) Master Mix (Qiagen, Hilden, Germany), each of the primers (1 $\mu \mathrm{l})($ Inqaba, SA), nuclease-free water $(6.5 \mu \mathrm{l})$ and DNA template $(5 \mu \mathrm{l})$ was used for the PCR amplification assay. The condition for the amplification included initial denaturation step $\left(94^{\circ} \mathrm{C}, 5 \mathrm{~min}\right)$, followed by 35 cycles $\left(92^{\circ} \mathrm{C}, 40 \mathrm{~s}\right)$, annealing $\left(58^{\circ} \mathrm{C}, 40 \mathrm{~s}\right)$, and the final extension step $\left(72^{\circ} \mathrm{C}, 10 \mathrm{~min}\right)$ was performed using a thermocycler (Bio-Rad Thermal cycler, USA). Five microlitres $(5 \mu \mathrm{l})$ of the amplicon was subjected to gel (1.5\% agarose) electrophoresis at 100 Volts for $45 \mathrm{~min}$ in Tris Boric EDTA buffer (pH 8.0) (0.089 M Tris, $0.089 \mathrm{M}$ boric acid, and $0.002 \mathrm{M}$ EDTA). Ethidium bromide ( $5 \mu \mathrm{l}$ of $0.5 \mathrm{mg} / \mathrm{ml}$ ) (Sigma-Aldrich, USA) was used for gel staining and DNA ladder (100 bp) (Thermo Scientific, (EU) Lithuania) was added into the gels as a standard. Finally, DNA bands were visualized under an ultraviolet transilluminator (Alliance 4.7, France).

\section{Delineation of Genus Acinetobacter into species}

The confirmed Acinetobacter isolates were delineated into species accordingly [30,52, 53] using a PCR assay. Firstly, optimization of conditions for A. baumannii, A. nosocomialis and A. pittii was carried out using species-specific primers (Table S1 under supplementary Section), while reference strains DSM- 
102929, DSM-102856, and DSM-9341 (DSMZ, Germany) were used as positive controls for A. baumannii, $A$. nosocomialis and $A$. pittii respectively. The PCR amplification was performed as stated in the previous section.

\section{Detection of virulence genes}

Polymerase chain reactions were also carried out for the identification of some Acinetobacter virulence genes including $a f a / d r a B C$, epsA, fimH, OmpA, PAl, sfa/focDE, and traT genes, which have been previously found in clinical samples $[54,55,56]$. The standard strain of $A$. baumannii DSM-30007 (DSMZ, Germany) was used as positive control. There was no positive control available for $A$. nosocomialis. The PCR assay and electrophoresis were conducted as earlier described.

\section{Statistical Analysis}

All statistical analyses were performed using the Statistica software v13.4.0.14 (64-bits). A simple factorial ANOVA was performed for the comparison of normally distributed data. The $p$-values of less than 0.05 were considered statistically significant for all the statistical tests performed.

\section{Abbreviations}

ACB: Acinetobacter calcoaceticus- baumannii complex;

ANOVA: Analysis of Variance;

APHA: American Public Health Association;

CFU: Colony Forming Unit;

CHROMagar: Chromogenic agar;

DNA: Deoxyribonucleic Acid;

EDTA: Ethylenediamine tetraacetic acid;

EspA: Exopolysaccharide A;

EU: European Union;

ICU: Intensive care unit;

L: Ladder;

LPS: Lipopolysaccharides;

$\mathrm{N}$ : Negative control;

ND: Not determined; 
NRF: National Research Foundation;

ompA: Outer membrane protein A precursor;

OMVs: Outer membrane vesicles;

P: Positive control;

PAl: Pathogenicity Island;

PCR: Polymerase Chain Reaction;

RSA: Republic of South Africa;

SAMRC: South African Medical Research Council;

TWAS: The World Academy of Science;

UFH: University of Fort Hare;

UK: United Kingdom;

USA: United States of America;

WWTPs: Wastewater treatment plants.

\section{Declarations}

\section{Ethics approval and consent to participate}

Collection of freshwater samples for research purposes in this region does not require governmental permission since freshwater resources investigated are within the University jurisdiction. Also, the need for ethical approval was waived by the Research Ethics Committee, University of Fort Hare, because samples analysed in this study do not require human or animal subjects.

\section{Consent for publication}

Not applicable

\section{Availability of data and materials}

The data used and analyzed during the current study are available from the corresponding author on reasonable request.

\section{Competing interests}

The authors declare that they have no competing interests. 


\section{Funding}

The research was funded by the National Research Foundation, South Africa/The World Academy of Science, Italy (NRF/TWAS) (grant numbers: 99767 and 116387) and the South African Medical Research Council (grant number: SAMRC/UFH/P790). The funders had no role in the study design, data collection and analysis, decision to publish, or manuscript preparation.

\section{Authors' contributions}

MAA conceived and designed the experiment, collected the water samples, isolated the Acinetobacter spp., performed the experiments, data and statistical analyses, and writing of the manuscripts.

AlO supervised the research, provided financial support, and reviewed the manuscript.

All authors read and approved the final manuscript.

\section{Acknowledgements}

Not applicable

\section{Authors' information}

Not applicable.

\section{References}

1. De Vos D, Jean-Paul P, Florence B, Serge J, Gilbert V, Thomas R, Elkana K, Petra B, Thierry P, Mony H, Walter H, Frank DP, Patrick S, Maia M, Pieter D, Mario V, Pierre B, Youri G, Bruno P, Tanny JR, Dijkshoorn L. Molecular Epidemiology and Clinical Impact of Acinetobacter calcoaceticus-baumannii complex in a Belgian Burn Wound Center. PLoS ONE. 2016; 11(5): e0156237.

2. Peleg AY, Seifert H, Paterson DL. Acinetobacter baumannii: emergence of a successful pathogen. Clin Microbiol Rev. 2008; 21, 538-582.

3. Hamouda A, Findlay J, Al Hassan L, Amyes SG. Epidemiology of Acinetobacter baumannii of animal origin. J. Antimicrob. Agents. 2011; 38, 314-318.

4. Huys G, Bartie K, Cnockaert M, Hoang Oanh DT, Phuong NT, Somsiri T, Chinabut S, Yussoff FD, Shariff M, Giacomini M, Teale A, Swings J. Biodiversity of chloramphenicol-resistant mesophilic heterotrophs from Southeast Asian aquaculture environments. Microbiol. 2007; 158, 228-235. doi:10.1016/j.resmic.2006.12.011.

5. Hrenovic J, Durn G, Goic-Barisic I, Kovacic A. Occurrence of an Environmental Acinetobacter baumannii Strain Similar to a Clinical Isolate in Paleosol from Croatia. Applied and Environmental Microbiology, 2014; 80(6): 2860-2866. 
6. Almasaudi SB. Acinetobacter as nosocomial pathogens: Epidemiology and resistance features. Saudi Journal of Biological Sciences. 2018; 25, 586-596.

7. Jung J, Park W. Acinetobacter species as model microorganisms in environmental microbiology: current state and perspectives. Appl. Microbiol. Biotechnol. 2015; 99, 2533-2548.

8. Doughari HJ, Ndakidemi PA, Human IS, Benade S. The ecology, biology and pathogenesis of Acinetobacter spp.: an overview. Microbes Environ. 2011; 26, 101-112.

9. Whitman TJ, Qasba SS, Timpone JG, Babel BS, Kasper MR, English JF, Sanders JW, Hujer KM, Hujer AM, Endimiani A. Occupational transmission of Acinetobacter baumannii from a United States serviceman wounded in Iraq to a health care worker. Infect. Dis. 2008; 47, 439-443.

10. Garnacho-Montero J, Amaya-Villar R, Ferrandiz-Millon C, Dıaz-Martın A, Lopez-Sanchez JM, GutierrezPizarraya A. Optimum treatment strategies for carbapenem-resistant Acinetobacter baumannii Expert Rev. Anti. Infect. Ther. 2015; 13(6): 769-77.

11. Falagas ME, Vardakas KZ, Kapaskelis A, Triarides NA, Roussos NS. Tetracyclines for multidrugresistant Acinetobacter baumannii International Journal of Antimicrobial Agents. 2015; 45, 455-460.

12. Basri R, Zueter AR, Mohamed Z, Alam MK, Norsa'adah B, Hasan SA, Hasan H, Ahmad F. Burden of bacterial meningitis: a retrospective review on laboratory parameters and factors associated with death in meningitis, Kelantan Malaysia. Nagoya J. Med. Sci. 2015; 77: 59-68.

13. Lai HH, Liou BH, Chang YY, Kuo SC, Lee YT, Chen TL, Fung CP. Risk factors and clinical outcome of sulbactam non-susceptibility in monomicrobial Acinetobacter nosocomialis Journal of Microbiology, Immunology and Infection. 2016; 49, 371-377.

14. Liu YM, Lee YZ, Kuo SC, Chen TL, Liu CP, Liu CE. Comparison between bacteremia caused by Acinetobacter pittii and Acinetobacter nosocomialis. Journal of Microbiology, Immunology and Infection. 2017; 50, 62-67.

15. Lee YT, Kuo SC, Yang SP, Lin YT, Chiang DH, Tseng FC, Chen TL, Fung CP. Bacteremic nosocomial pneumonia caused by Acinetobacter baumannii and Acinetobacter nosocomialis: a single or two distinct clinical entities. European Society of Clinical Microbiology and Infectious Diseases, CMI. 2012; $19,640-645$.

16. Nho JS, Jun SH, Oh MH, Park TI, Choi CW, Kim S, Choi CH, Lee JC. Acinetobacter nosocomialis secretes outer membrane vesicles that induce epithelial cell death and host inflammatory responses. Microbial Pathogenesis. 2015; 81, 39-45.

17. Lee CR, Lee JH, Park M, Park KS, Bae IK, Kim YB, Cha CJ, Jeong BC, Lee SH. Biology of Acinetobacter baumannii: Pathogenesis, Antibiotic Resistance Mechanisms, and Prospective Treatment Options. Frontiers in Cellular Infection Microbiology. 2017; 7(March) https://doi.org/10.3389/fcimb.2017.00055. 
18. Kurcik-Trajkovska B. Acinetobacter - a serious enemy threatening hospitals worldwide. Macedonian Journal of Medical Science. 2009; 2,157-162.

19. Kanafani AZ, Kanj SS. Ministry of Health, Kingdome of Saudi Arabia. 2014. http://www.uptodate.com/contents/acinetobacterinfection-treatment-and-prevention.

20. Kim SW, Oh MW, Jun SH, Jeon H, Kim S, Kim K, Lee YC, Lee JC. Outer Membrane Protein A plays a role in pathogenesis of Acinetobacter nosocomialis. Virulence. 2016; 7:4, 413-426, DOI: 10.1080/21505594.2016.1140298.

21. Ellis TN, Kuehn MJ. Virulence and immunomodulatory roles of bacterial outer membrane vesicles. Microbiology and Molecular Biology Review. 2010; 74, 81-94. doi: 10.1128/MMBR.00031-09.

22. Kwon So, Gho YS, Lee JC, Kim SI. Proteome analysis of outer membrane vesicles from a clinical Acinetobacter baumannii FEMS Microbiology Letter. 2009; 297, 150-156. doi: 10.1111/j.15746968.2009.01669.

23. Jun SH, Lee JH, Kim BR, Kim SI, Park TI, Lee JC, Lee YC. Acinetobacter baumannii outer membrane vesicles elicit a potent innate immune response via membrane proteins. PLoS ONE. 2013; 8, e71751. doi: 10.1371/journal.pone.0071751.

24. Fiester SE, Arivett BA, Schmidt RE, Beckett AC, Ticak T, Carrier MV, Ghosh R, Ohneck EJ, Metz ML, Jeffries MKS, Actis LA. Iron-regulated phospholipase $C$ activity contributes to the cytolytic activity and virulence of Acinetobacter baumannii. PLoS ONE. 2016; 11:e0167068. doi:

10.1371/journal.pone.0167068.

25. Diancourt L, Passet V, Nemec A, Dijkshoorn L, Brisse S. The population structure of Acinetobacter baumannii: expanding multiresistant clones from an ancestral susceptible genetic pool. PLoS ONE. 2010; e10034.doi: 10.1371/journal.pone.0010034.

26. Fernando DM, Khan IUH, Patidar R, Lapen DR,Talbo G, Topp E, Kumar A. Isolation and Characterization of Acinetobacter baumannii recovered from Campylobacter Selective Medium. Frontiers in Microbiology; 2016; 7:1871.

27. Maravic A, Skocibusic, M, Fredotovic Z, Samanic I, Cvjetan S, Knezovic M, Puizina J. Urban riverine environment is a source of multidrug-resistant and ESBL-producing clinically important Acinetobacter Environ Sci Pollut Res. 2016; 23, 3525-3535.

28. Krizova L, Maixnerovaa M, Sedob O, Nemec A. Acinetobacter bohemicus nov. wide spread in natural soil and water ecosystems in the Czech Republic. Systematic and Applied Microbiology. 2014; 37, 467-473.

29. Xiong W, Sun Y, Zhang T, Ding X, Li Y, Wang M, Zeng Z. Antibiotics, Antibiotic Resistance Genes, and Bacterial Community Composition in Fresh Water Aquaculture Environment in China. Microb Ecol. 2015; 70:425-432. 
30. Chen TL, Lee YT, Kuo SC, Yang SP, Fung CP, Lee SD. Rapid identification of Acinetobacter baumannii, Acinetobacter nosocomialis and Acinetobacter pittii with a multiplex PCR assay. Journal of Medical Microbiology, 2014; 63, 1154-1159.

31. Chiang MC, Kuo SC, Chen YC, Lee YT, Chen TL, Fung CP. Polymerase chain reaction assay for the detection of Acinetobacter baumannii in endotracheal aspirates from patients in the intensive care unit. Journal of Microbiology, Immunology and Infection. 2011; 44, 106-110.

32. Dijkshoorn L, Nemec A, Seifert H. An increasing threat in hospitals: multidrug-resistant Acinetobacter baumannii. Nat Rev Microbiol. 2007; 5, 939-951.

33. Park YK, Jung SI, Park KH, Kim DH, Choi JY, Kim SH, Ko KS. Changes in antimicrobial susceptibility and major clones of Acinetobacter calcoaceticus-baumannii complex isolates from a single hospital in Korea over 7 years. Journal of Medical Microbiology. 2012; 61(1) 71-79.

34. Anh NT, Thieu Nga TV, Tuan HM, Tuan NS, Dao Y, Chau NVV, Baker S, Duong HHT. Molecular epidemiology and antimicrobial resistance phenotypes of Acinetobacter baumannii isolated from patients in three hospitals in southern Vietnam. Journal of Medical Microbiology. 2017; 66:46-53.

35. Berlau J, Aucken HM, Houang E, Pitt TL. Isolation of Acinetobacter spp including baumannii from vegetables: implications for hospital-acquired infections. Journal of Hospital Infection. 1999; 42: 201204.

36. Ambrosi C, Scribano D, Aleandri M, Zagaglia C, Di Francesco L, Putignani L, Palamara AT. Acinetobacter baumannii Virulence Traits: A Comparative Study of a Novel Sequence Type with Other Italian Endemic International Clones. Front. Microbiol. 2017; 8:1977. doi: 10.3389/fmicb.2017.01977.

37. Sato Y, Unno Y, Kawakami S, Ubagai T, Ono Y. Virulence characteristics of Acinetobacter baumannii clinical isolates vary with the expression levels of omps. Journal of Medical Microbiology. 2017; 66:203-212.

38. Antunes LCS, Imperi F, Carattoli A, Visca P. Deciphering the Multifactorial Nature of Acinetobacter baumannii PLoS ONE. 2011; 6(8): e22674. doi:10.1371/journal.pone.0022674.

39. Smith MG, Gianoulis TA, Pukatzki S, Mekalanos JJ, Ornston LN, Gerstein M, Snyder M. New insights into Acinetobacter baumannii pathogenesis revealed by high-density pyrosequencing and transposon mutagenesis. Genes and Development. 2007; 21:601-614.

40. McConnell MJ, Actis L, Pachon J. Acinetobacter baumannir: human infections, factors contributing to pathogenesis and animal models. FEMS Microbiol Rev. 2013; 37: 130-155.

41. Gaddy JA, Tomaras AP, Actis LA. The Acinetobacter baumannii 19606 OmpA protein plays a role in biofilm formation on abiotic surfaces and in the interaction of this pathogen with eukaryotic cells. Infection and Immunity. 2009; 77(8), 3150-3160. 
42. Smani Y, Dominguez-Herrera J, Pachon J. Association of the outer membrane protein Omp33 with fitness and virulence of Acinetobacter baumannii. Journal of Infectious Disease. 2013; 208, 15611570. doi: $10.1093 /$ infdis/jit386.

43. Lee JC, Oh JY, Kim KS, Jeong YW, Park JC, Cho JW. Apoptotic cell death induced by Acinetobacter baumannii in epithelial cells through caspase-3 activation. APMIS. 2001; 109:679-684.

44. Smani Y, Domnguez-Herrera J, Pachon J. Rifampin protects human lung epithelial cells against cytotoxicity induced by clinical multi and pandrug-resistant Acinetobacter baumannii. European Congress of Clinical Microbiology and Infectious Diseases. 2011; Vienna, Austria, April 2010.

45. Choi CH, Lee EY, Lee YC, Park TI, Kim HJ, Hyun SH, Kim SA, Lee SK, Lee JC. Outer membrane protein 38 of Acinetobacter baumannii localizes to the mitochondria and induces apoptosis of epithelial cells. Cellular Microbiology. 2005; 7, 1127-1138. doi: 10.1111/j.1462-5822.2005.00538.

46. Lee JS, Choi CH, Kim JW, Lee JC. Acinetobacter baumannii outer membrane protein A induces dendritic cell death through mitochondrial targeting. Journal of Microbiology, 2010; 48, 387-392. doi: 10.1007/s12275-010-0155-1.

47. Sugawara E, Nikaido H. OmpA is the principal nonspecific slow porin of Acinetobacter baumannii. Bacteriol. 2012; 194, 4089-4096. doi: 10.1128/JB.00435-12.

48. Smani Y, Fabrega A, Roca I, Sanchez-Encinales V, Vila J, Pachon J. Role of OmpA in the multidrug resistance phenotype of Acinetobacter baumannii. Antimicrob. Agents Chemother. 2014; 58, 18061808. doi: 10.1128/AAC.02101-13.

49. Sibanda T, Chigor VN, Koba S, Obi CL, Okoh Al. Characterisation of the physicochemical qualities of a typical rural-based river: ecological and public health implications. Int. J. Environ. Sci. Technol. 2014; 11:1771-1780.

50. American Public Health Association, APHA. Standard Methods for the Examination of Water and Wastewater, 20th Ed.; (APHA): Washington, DC, USA. 2005.

51. Maugeri TL, Carbone M, Fera MT, Gugliandolo C. Detection and differentiation of Vibrio vulnificus in seawater and plankton $\mathrm{f}$ a coastal zone of the Mediterranean Sea. Research in Microbiology. 2006; 157(2), 194-200.

52. Chen TL, Siu LK, Wu RCC, Shaio MF, Huang LY, Fung CP, Lee CM, Cho WL. Comparison of one-tube multiplex PCR, automated ribotyping and intergenic spacer (ITS) sequencing for rapid identification of Acinetobacter baumannii. Clin Microbiol Infect; 2007; 13: 801-806.

53. Higgins PG, Wisplinghoff $\mathrm{H}$, Krut $\mathrm{O}$, Seifert $\mathrm{H}$. A PCR-based method to differentiate between Acinetobacter baumannii and Acinetobacter genomic species 13TU. Clin Microbiol Infect. 2007; 13:1199-1201. 
54. Thummeepak R, Kongthai P, Leungtongkam U, Sitthisak S. Distribution of virulence genes involved in biofilm formation in multi-drug resistant Acinetobacter baumannii clinical isolates. International Microbiology. 2016; 19:121-129 doi:10.2436/20.1501.01.270.

55. Momtaz H, Seifati SM, Tavakol M. Determining the prevalence and detection of the most prevalent virulence genes in Acinetobacter baumannii isolated from hospital infections. Int J Med Lab. 2015; 2(2):87-97.

56. Braun G, Vidotto MC. Evaluation of Adherence, Hemagglutination, and Presence of Genes Codifying for Virulence Factors of Acinetobacter baumannii Causing Urinary Tract Infection. Mem Inst Oswaldo Cruz, Rio de Janeiro, 2004; 99(8): 839-844.

\section{Tables}

Table 1: Summary of the relative abundance of the genus Acinetobacter and two clinically important species in the freshwater studied

\begin{tabular}{llllll}
\hline $\begin{array}{l}\text { Rivers } \\
\text { sampled }\end{array}$ & $\begin{array}{l}\text { Presumptive } \\
\text { isolates }\end{array}$ & Acinetobactergenus & $\begin{array}{l}\text { Delineated Acinetobacter } \\
\text { species }\end{array}$ & $\begin{array}{l}\text { Other } \\
\text { species (ND) }\end{array}$ \\
& & & A. & A. & \\
& & & baumannii & nosocomialis & \\
\hline Great Fish & 370 & $285(77.01 \%)$ & $153(53.68 \%)$ & $16(5.61 \%)$ & $116(40.70 \%)$ \\
Keiskamma & 309 & $219(70.87 \%)$ & $102(46.58 \%)$ & $3(1.37 \%)$ & $114(52.06 \%)$ \\
Tyhume & 428 & $340(79.44 \%)$ & $155(45.59 \%)$ & $4(1.18 \%)$ & $181(53.24 \%)$ \\
Total & 1107 & $844(76.24 \%)$ & $410(48.58 \%)$ & $23(2.73 \%)$ & $411(48.70 \%)$ \\
\hline
\end{tabular}

$\mathrm{ND}=$ not determined

Table 2: Virulence gene factors of $A$.baumannii and A. nosocomialis isolates in addition to which river they belong to. 
Virulence

gene

\section{Sample sites}

Kieskamma
Great Fish
Tyhume
A. baumannii
A.
A.
A.
A.
A.

\begin{tabular}{|c|c|c|c|c|c|c|}
\hline & & $\begin{array}{r}s \\
(\mathrm{n}=16)\end{array}$ & $\begin{array}{c}i \\
(\mathrm{n}=102)\end{array}$ & $\begin{array}{r}s \\
(\mathrm{n}=3)^{-}\end{array}$ & $\begin{array}{c}i \\
(\mathrm{n}=155)\end{array}$ & $\begin{array}{r}S \\
(\mathrm{n}=4)\end{array}$ \\
\hline$A f a / d r a B C$ & $16(10.46 \%)$ & - & $4(3.92 \%)$ & - & $8(5.81)$ & 1 (25\%) \\
\hline \multirow[t]{2}{*}{$\operatorname{esp} A$} & 36 & - & 15 & - & 44 & 1 (25\%) \\
\hline & (23.53\%) & & (14.71\%) & & (28.39\%) & \\
\hline \multirow[t]{2}{*}{$\mathrm{fimH}$} & 44 & - & 26 & $1(33.33 \%)$ & 30 & 1 (25\%) \\
\hline & (28.76\%) & & $(25.49 \%)$ & & (19.36\%) & \\
\hline \multirow[t]{2}{*}{$O m p A$} & 69 & - & 52 & - & 77 & - \\
\hline & $(45.10 \%)$ & & (50.98\%) & & $(49.68 \%)$ & \\
\hline PAI & $2(1.31 \%)$ & $1(6.26 \%)$ & $3(2.94 \%)$ & - & - & - \\
\hline$S f a / f o c D E$ & $3(1.96 \%)$ & - & $4(3.92 \%)$ & - & $7(4.52 \%)$ & - \\
\hline \multirow[t]{2}{*}{$\operatorname{traT}$} & 19 & - & $4(3.92 \%)$ & - & 22 14.19\%) & - \\
\hline & $(12.42 \%)$ & & & & & \\
\hline
\end{tabular}

\section{Figures}

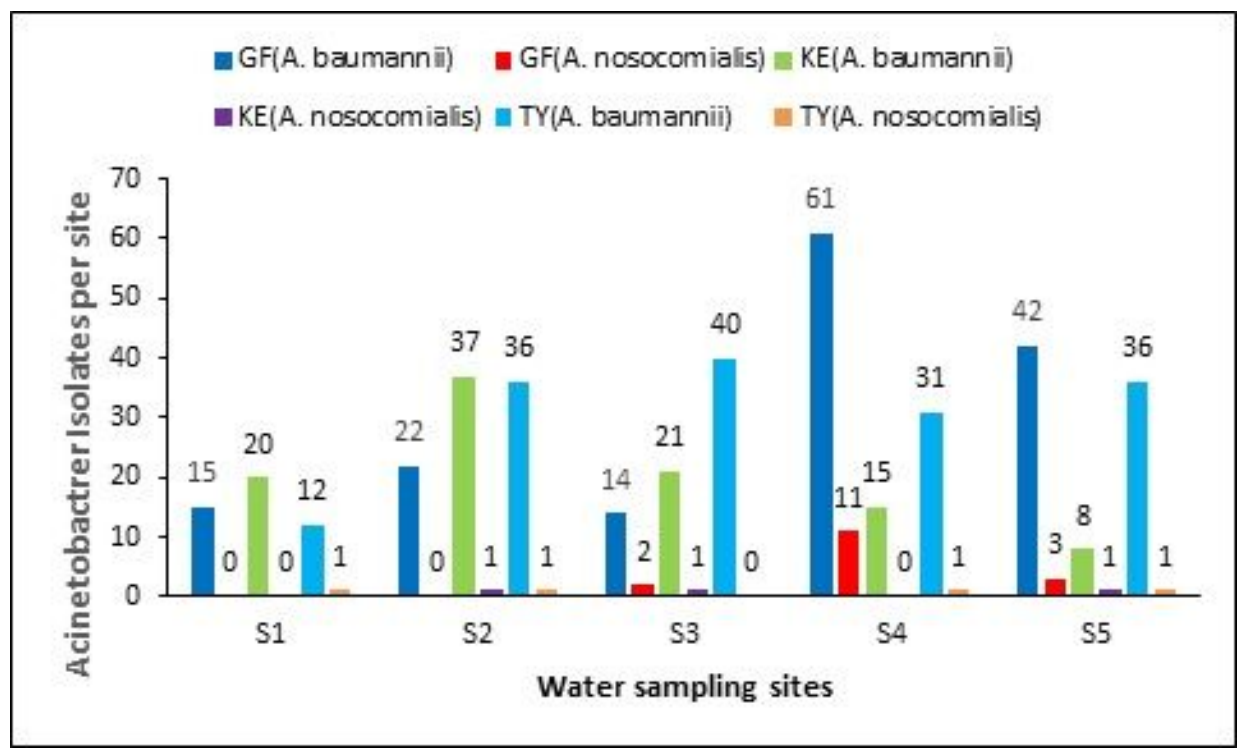

Figure 1 
Isolates of A. baumannii and A. nosocomialis recovered from each of the sampling sites in Great Fish (GF), Keiskamma (KE) and Tyhume (TY) Rivers. The number of isolates presented in this here represent a pool of the five sampling sites.

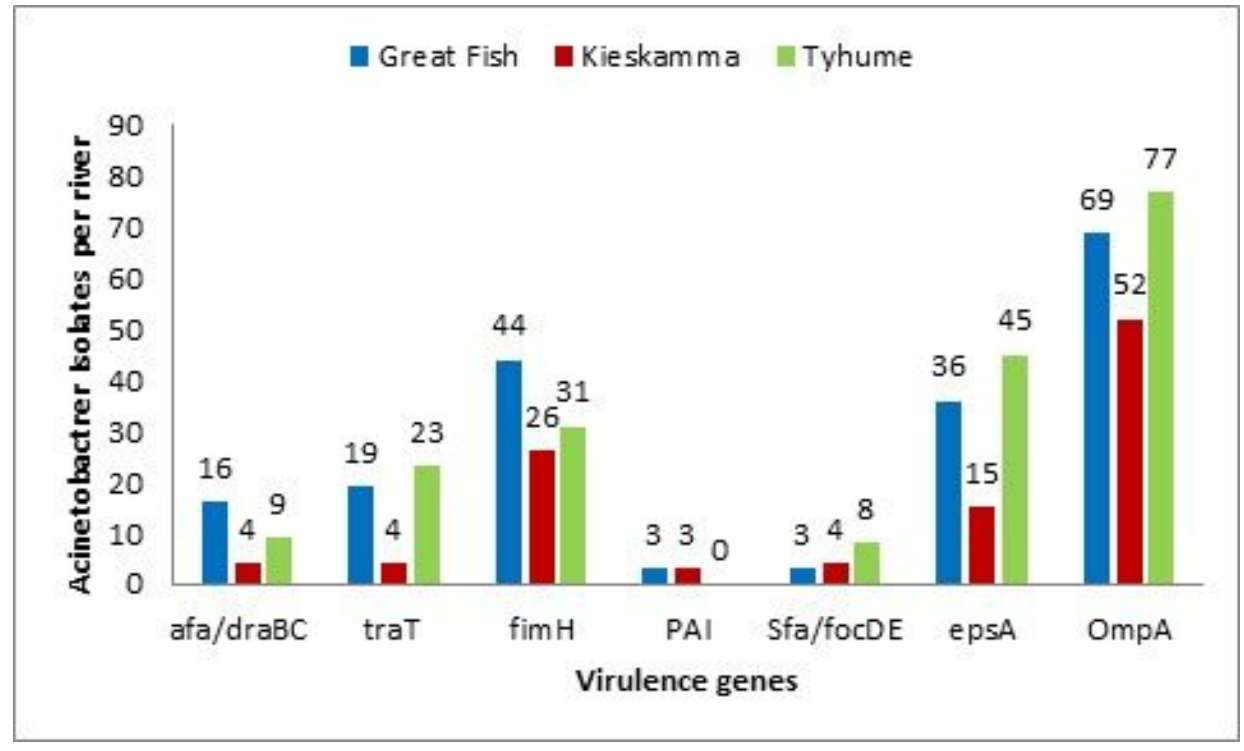

\section{Figure 2}

Virulence genes in both Acinetobacter species recovered from each of the rivers.

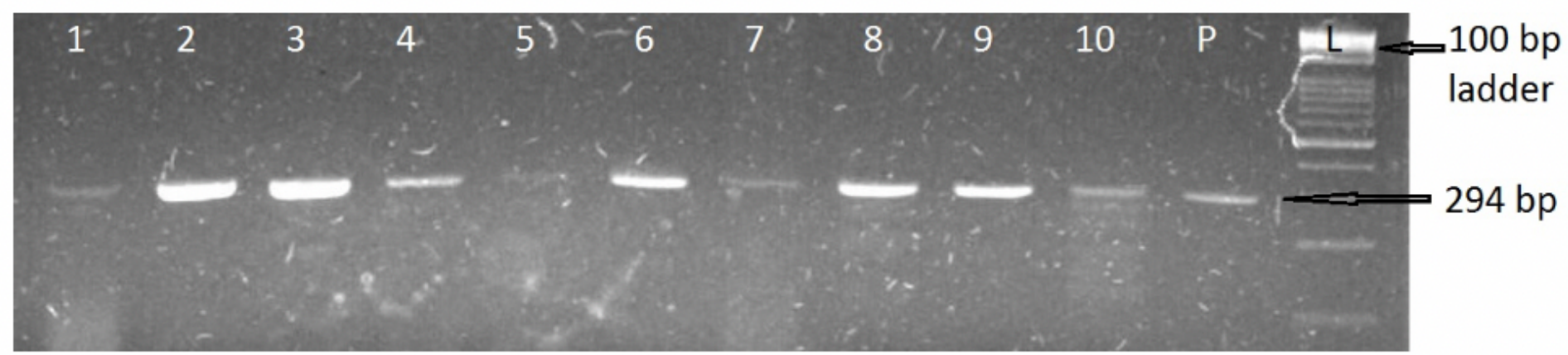

\section{Figure 3}

PCR analyses resolved by gel electrophoresis showing confirmed $A$. nosocomialis targeting the gyrBgene at 294 bp. L= DNA Ladder (100bp); P= Positive control (A. nosocomialis, DSM 102856); Lanes 1 to $10=$ Selected A. nosocomialis samples. 


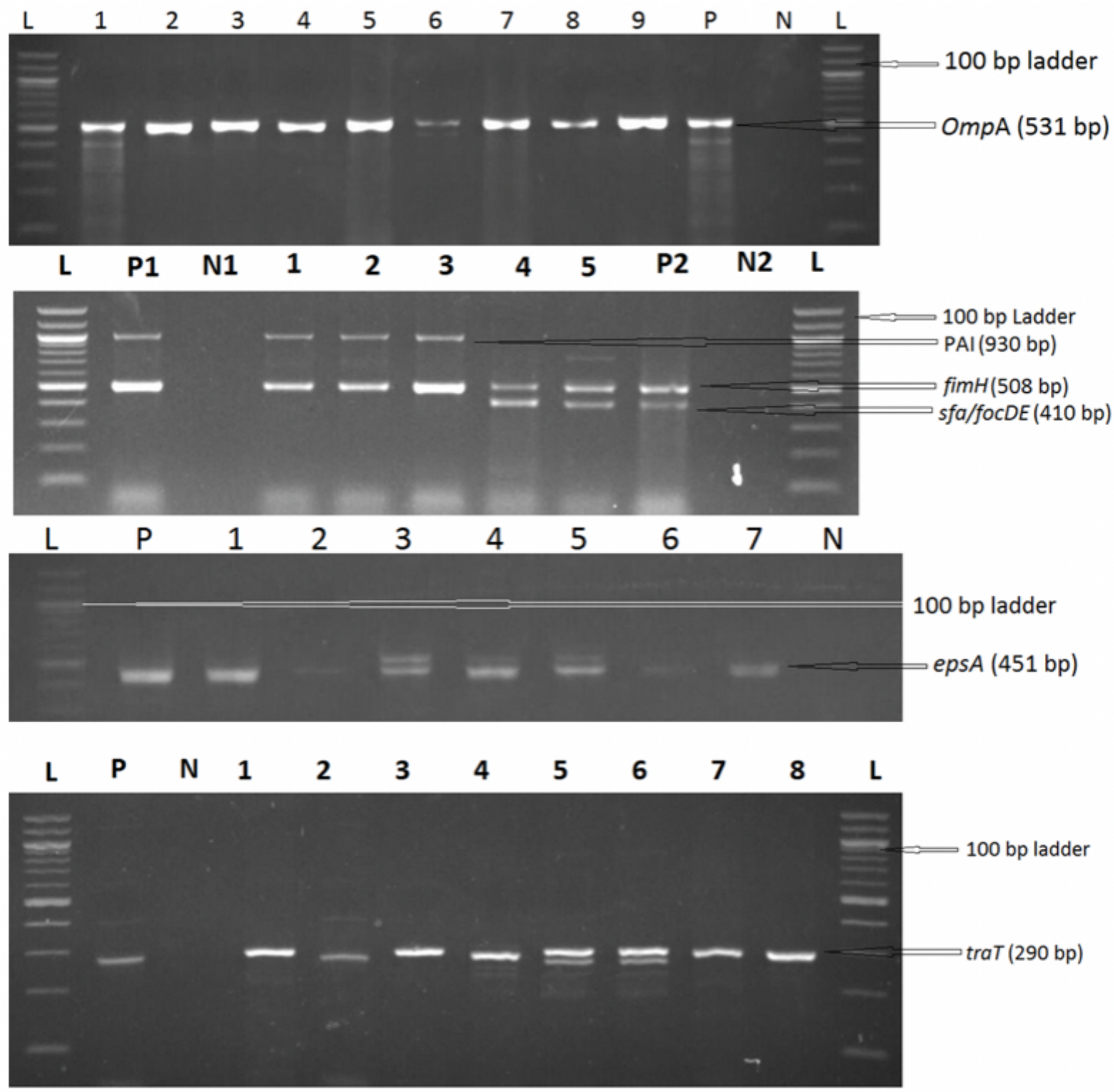

\section{Figure 4}

PCR analyses resolved by gel electrophoresis showing confirmed virulence genes OmpA, PAl, fimH, sfa/focDE, espA and traT at 531, 930, 506, 410, 451 and 290 base pairs respectively. L= DNA Ladder (100bp); Lane 1 to 9 (overall) = Selected Acinetobacter isolates; $\mathrm{N}=$ Negative control; $\mathrm{P}=$ Positive control (A. baumannii, DSM Number: 102929). 


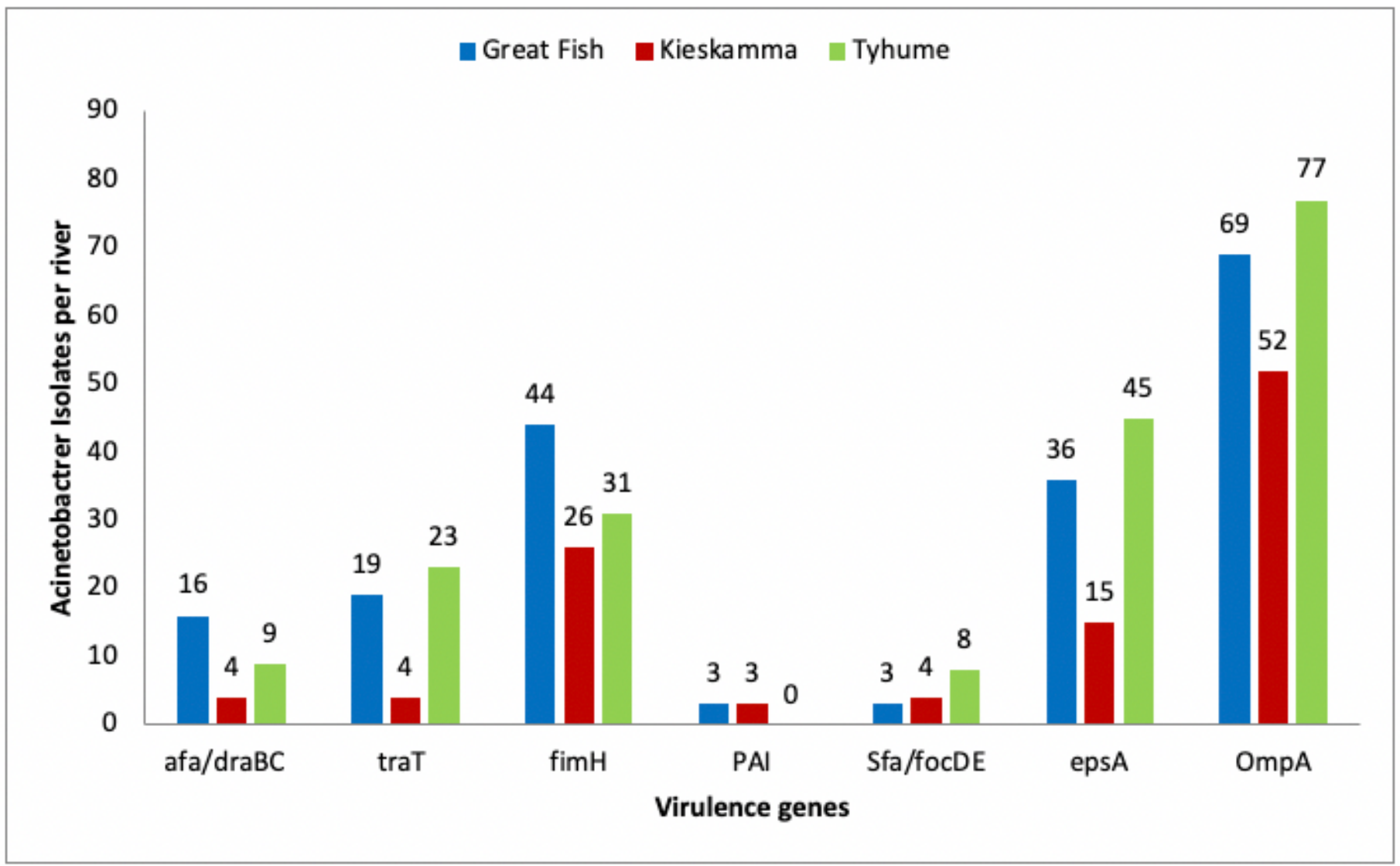

Figure 5

Confirmed virulence genes in the Acinetobacter species recovered from each of the rivers. 